\title{
DESIGN DEVELOPMENT OF INDONESIAN TEACHING MATERIALS IN HEALTH INSIGHTS FOR ELEMENTARY SCHOOLS IN COVID-19 PANDEMIC
}

\author{
Jannah Ulfah $^{1}$, Aninditya Sri Nugraheni ${ }^{2}$ \\ ${ }^{1,2}$ Universitas Islam Negeri Sunan Kalijaga Yogyakarta, Yogyakarta, Indonesia \\ ${ }^{1}$ janahulfa9@gmail.com, ${ }^{2}$ aninditya@uinsuka.ac.id
}

\section{DESAIN PENGEMBANGAN MATERI AJAR BAHASA INDONESIA BERWAWASAN KESEHATAN DI SEKOLAH DASAR PADA MASA PANDEMI COVID-19}

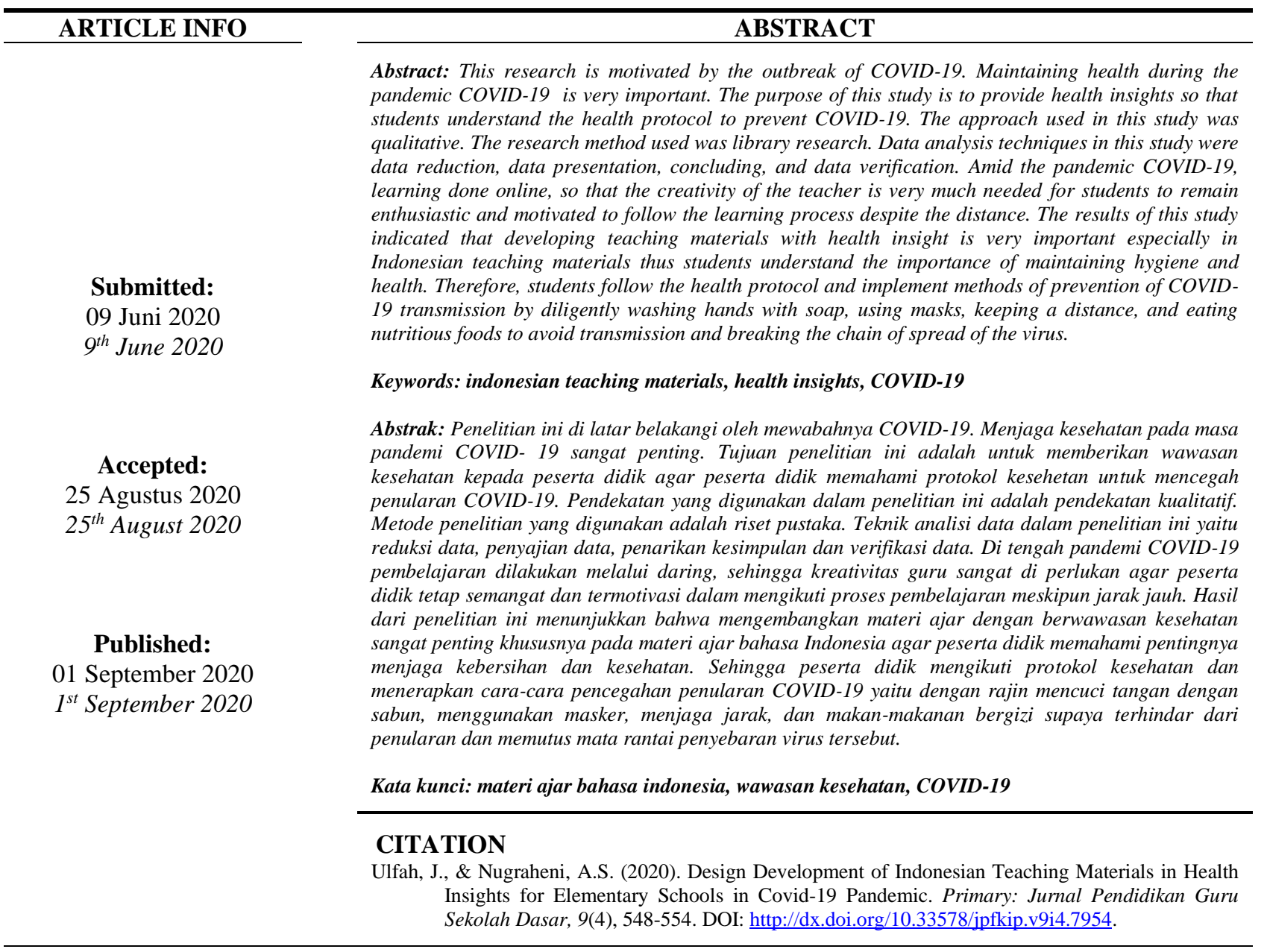

\section{PENDAHULUAN}

Mewabahnya virus baru yang telah menggemparkan dunia diawal tahun 2020 yaitu Coronavirus Disease 2019 (COVID-19) disebabkan oleh Severa Acute Respiratory

Syndrome Coronavirus-2 (SARS-Cov-2). Virus ini ditemukan pada bulan Desember 2019 yang diketahui berasal dari Wuhan, Provinsi Hubei. Belum diketahui pasti sumber penularan virus 
tersebut, akan tetapi kasus yang muncul pertama kali dikaitkan dengan pasar ikan di Wuhan (Susilo, dkk. 2020).

COVID-19 saat ini merupakan suatu wabah yang tidak bisa diabaikan begitu saja. Penyebaran virus ini cukup signifikan karena hampir seluruh negara merasakan dampaknya termasuk Indonesia. Penularannya dari manusia ke manusia terutama melalui tetesan pernapasan yaitu batuk dan bersin. Virus ini dapat tetap bertahan hingga tiga hari dengan plastic dan stainless steel, sedangkan dalam aerosol dapat bertahan selama tiga jam (Gorbalennya, 2020). Terkait pencegahan penularan virus ini pemerintah mengambil beberapa kebijakan untuk memutus mata rantai penyebaran COVID-19 diantaranya memberlakukan kegiatan lockdown (Yunus \& Rezki, 2020). Kegiatan lockdown ini merupakan bagian dari peraturan perundang-undangan yang tertuang dalam UU No 6 tahun 2018 yaitu tentang kekarantinaan kesehatan yang membahas tentang kekarantinaan kesehatan di pintu masuk dan di wilayah dilakukan pengamatan mengenai penyakit dan faktor risiko kesehatan masyarakat (UU, 2018).

Pemerintah menghimbau kepada masyarakat untuk melakukan physical distancing yaitu menjaga jarak antar masyarakat, menghindari segala kativitas dalam bentuk kerumunan, dan menghindari adanya pertemuan yang melibatkan banyak orang. Selain itu pemerintah juga menerapkan kebijakan Work From Home (WFH) sebagai upaya agar masyarakat dapat menyelesaikan segala pekerjaannya di rumah. Kebijakan ini pun berdampak pada bidang Pendidikan di Indonesia, yaitu seluruh instansi penyelenggara pendidikan baik formal, non formal hingga perguruan tinggi.

Terkait hal tersebut, Mendikbud Nadiem Makarim mengambil kebijakan yaitu proses pembelajaran di sekolah ditiadakan selama masa pandemi COVID-19 dan menggantinya dengan sistem pembelajaran secara daring. Walaupun sistem pembelajaran dilakukan secara daring, Mendikbud Nadiem Makarim tetap menghimbau kepada seluruh guru dan peserta didik untuk selalu menjaga kebersihan dengan mengeluarkan Surat Edaran Nomor 3 tahun 2020 tentang pencegahan
COVID-19 pada satuan pendidikan. Dalam surat edaran tersebut menghimbau kepada seluruh warga satuan pendidikan untuk selalu membiasakan pola hidup bersih, sehat, dan kegiatan olahraga yang teratur (Surat Edaran, 2020). Dengan dikeluarkannya surat edaran tersebut, maka guru pun harus memberikan pemahaman kepada peserta didik untuk selalu menjaga kebersihan agar tubuh selalu sehat dan terhindar dari penularan COVID19.

Pada situasi pandemi COVID-19 saat ini guru harus memastikan kegiatan pembelajaran tetap berjalan, meskipun jarak jauh. Pembelajaran jarak jauh ini sebelumnya sudah diterapkan oleh beberapa instansi seperti Universits Terbuka (UT) Bandung yang sudah menerapkan sistem pendidikan jarak jauh sebelum adanya pandemi COVID-19 (Thaib, dkk. 2017). Pendidik dapat menggunakan pembelajaran dengan menerapkan metode E-Learning dengan memanfaatkan kemajuan teknlogi informasi dan komunikasi sebagai media pembelajaran. Dengan begitu proses pembelajaran akan tetap berjalan, meskipun tidak semaksimal seperti proses pembelajaran yang dilakukan di sekolah. Setiap memberikan tugas kepada peserta didik, guru hendaknya terlebih dahulu memberikan pesan tentang pencegahan penularan COVID-19, yaitu selalu menjaga kebersihan diri, mencuci tangan dengan sabun, dan menghindari kegiatan diluar rumah yang dirasa tidak terlalu penting.

Pemahaman mengenai pencegahan penyebaran COVID-19 ini harus disampaikan oleh guru dengan baik kepada peserta didik, terutama pada anak usia dasar. Karena anak usia dasar memiliki pola pikir yang terbatas, dan masih memerlukan perhatian yang lebih (Andesta, 2018). Berdasarkan situasi keadaan seperti ini, pendidik perlu mengembangkan materi ajar di SD/MI dengan berwawasan kesehatan. Materi ajar dalam proses pembelajaran harus memberikan dampak yang positif bagi peserta didik dan materi ajar sangat memberikan pengaruh terhadap keberhasilan peserta didik. Oleh karena itu penyampaian materi ajar harus disampaikan dengan baik oleh guru agar peserta didik dapat memahami dengan baik materi yang disampaikan (Wahyanti dan Sutopo, 2013). 
Beberapa tugas mata pelajaran harus terintegrasi untuk mendorong peserta didik agar lebih sadar dan memahami pencegahan penularan COVID-19. Sebagai contoh pada mata pelajaran bahasa Indonesia guru memberikan tugas kepada peserta didik untuk membaca dan memahami reverensi tentang COVID-19, membuat teks tentang pencegahan penularan virus COVID-19, dan lain sebagainnya. Materi ajar bahasa Indonesia dengan berwawasan kesehatan yang diberikan

\section{KAJIAN TEORETIS \\ Materi Ajar}

Materi ajar merupakan segala bentuk materi yang digunkan untuk membantu guru dalam melaksanakan kegiatan proses pembelajaran (Tomlinson, 1998). Materi ajar dapat diartikan sebagai pengetahuan, keterampilan maupun sikap yang harus dipelajari peserta didik dalam rangka mencapai kompetensi inti yang telah ditentukan. Memberikan materi ajar adalah tugas seorang guru untuk dapat mengolah dan mengemas materi. Guru harus dapat mengaitkan materi ajar dengan kehidupan sehari-hari supaya materi yang diberikan dapat dipahami dengan baik oleh peserta didik materi ajar yang diberikan oleh guru sangat berpengaruh terhadap keberhasilan pembelajaran secara kesuluruhan dan harus memberikan dampak positif bagi peserta didik.

Berdasarkan Depdiknas (2008) materi ajar diklasifikasikan menjadi lima, yaitu fakta, konsep, prinsp, prosedur, dan sikap. Berikut pengertian dari masing-masing klasifikasi. 1) Fakta, merupakan segala sesuatu yang berwujud kenyataan dan kebenaran,yaitu seperti nama-nama objek, peristiw sejarah, lambing, nama tempat, nama orang, nama komponen suatu benda, dan lain sebagainya. 2) Konsep, merupakan hal-hal yang berupa pengertian-pengertian baru yang timbul dari hasil pemikiran, seperti definisi, hakikat, ciri khusus, inti atau isi, dan lain sebagainya. 3) Prinsip, yaitu berupa hal utama, pokok, dan memiliki posisi penting, seperti rumus, paradigma, teorama, dan hubungan antar konsep yang menggambarkan implikasi sebab akibat. 4) Prosedur, yaitu berupa langkah-langkah sistematis atau berurutan dalam melakukan suatu aktivitas dan kronologi suatu kepada peserta didik pada masa pandemi COVID19 ini memang penting untuk memberikan pemahaman kepada pesera didik untuk selalu menjaga kesehatan dengan mengikuti protokol kesehatan. Oleh karena itu disini penulis ingin mencoba mengkaji tentang hal-hal yang berkaitan dengan pengembangan materi ajar bahasa Indonesia berwawasan kesehatan di SD/MI pada masa pandemi COVID-19.

system. 5) Sikap atau nilai, yaitu merupakan hasil belajar aspek sikap, seperti nilai kejujuran, tolongmenolong, kasih sayang, semangat, minat belajar, dan lain sebagainya.

Supaya materi ajar bermakna bagi peserta didik, sebaiknya materi ajar yang dikembangkan oleh guru dapat menumbuhkan rasa ingin tahu, ketertarikan, dan perhatian bagi peserta didik. Oleh karena itu, materi ajar yang dikembangkan harus menarik dan menyenangkan. Dalam hal ini perlu diupayakan adanya unsur bermain dalam belajar. Masalah yang ada saat pandemi COVID-19 ini adalah perlunya bagi setiap orang untuk selalu menjaga kesehatan. Karena itu guru hendaknya dapat mengembangkan materi ajar Bahasa Indonesia dengan berwawasan kesehatan agar dapat menjadi pembelajaran bagi peserta didik untuk mencegah penularan COVID-19.

\section{Kesehatan}

Kesehatan adalah sejahteranya keadaan badan, jiwa, dan sosial yang menjadikan setiap orang hidup prduktif. Kesehatan tidak hanya terbatas secara fisik, mental, maupun sosial, akan tetapi kesehatan dipandang sebagai alat atau sarana untuk hidup produktif. Dengan begitu, upaya kesehatan yang dilakukan oleh setiap orang hendaknya diarahkan untuk mencapai kesehatan yang cukup agar hidupnya produktif. Beberapa pola hidup sehat yang dapat diterapkan diantaranya mengatur makanan dan pola makan, menjaga kesehatan pribadi, mengatur istirahat, dan berolahraga teratur (Suharjana, 2012).

Berdasarkan UU RI No. 36 Tahun 2009 tentang kesehatan pada BAB II pasal 3 yang 


\section{PRIMARY: JURNAL PENDIDIKAN GURU SEKOLAH DASAR}

VOLUME 9 NOMOR 4 AGUSTUS 2020

ISSN: 2303-1514 | E-ISSN: 2598-5949

menyatakan: "pembangunan kesehatan bertujuan untuk meningkatkan kesadaran, kemauan, dan kemampuan hidup sehat bagi setiap orang agar terwujud derajat kesehatan masyarakat yang setinggi-tingginya, sebagai investasi bagi pembangunan sumber daya manusia produktif secara sosial dan eknomi” (UU, 2009). Konsep kesehatan sangat penting untuk membantu memberikan kesadaran kepada masyarakat tentang pentingnya menjaga kesehatan secara menyeluruh. Kesadaran menjaga kesehatan merupakan suatu kepedulian dan perhatian untuk menjadi lebih baik dan termotivasi dalam memperbaiki, mempertahankan, menjaga kesehatan, dan kualitas hidup dengan selalu menerapkan pola hidup sehat. Upaya yang dapat dilakukan untuk menerapkan pola hidup sehat adalah dengan mengkonsumsi makanan organik. Banyak yang beranggapan

\section{METODE PENELITIAN}

Pendekatan yang digunakan dalam penelitian ini adalah pendekatan kualitatif. Data yang dikumpulkan dalam penelitian ini berupa kata-kata, gambar dan bukan angka-angka, (Sugiono, 2013). Metode penelitian yang digunakan adalah studi pustaka (library research). Penelitian ini bertujuan untuk mengumpulkan data dan informasi melalui berbagai macam material, seperti : buku-buku, majalah, dokumen, literaturliteratur dan catatan lainnya yang mendukung pemecahan masalah dalam penelitian ini. Studi pustaka tidak hanya sekedar urusan membaca dan mencatat literatur atau buku-buku sebagaimana yang sering dipahami banyak orang selama ini. bahwa mengkonsumsi $\mathrm{m}$ akanan organik lebih aman dan dapat memberikan manfaat lebih besar bagi kesehatan tubuh (Shaharudin, dkk., 2010)

Di tengah wabah COVID-19 ini salah satu cara untuk selalu sehat adalah dengan selalu menjaga kebersihan diri. Menjaga kebersihan diri merupakan langkah awal untuk mewujudkan masyarakat yang sehat. Kebersihan diri yang tidak baik dapat berakibat kesulitan dalam mengembangkan dan mengusahakan masyarakat yang sehat. Oleh karena itu, menjaga kebersihan pribadi merupakan hal yang sangat penting. Terlebih pada pada saat ini, ditengah mewabahnya pandemi COVID-19, menjaga kebersihan diri merupakan hal yang penting dan sangat dianjurkan untuk mencegah penularan dan memutus mata rantai penyebaran virus tersebut.

Studi pustaka atau library research merupakan serangkaian kegiatan yang berkenaan dengan metode pengumpulan data pustaka, membaca dan mencatat serta mengolah bahan penelitian (Zed, 2008)

Teknik pengumpulan data yang digunakan dalam penelitian ini adalah dokumentasi. Dokumentasi digunakan untuk mendapatkan datadata yang berhubungan dengan materi bahasa Indonsesia dan kesehatan sebagai pencegahan penularan COVID-19. Data yang dikumpulkan kemudian dianalisis dengan langkah-langkah yaitu reduksi data, penyajian data, penarikan kesimpulan dan verifikasi data (Nusa Putra, 2012) .

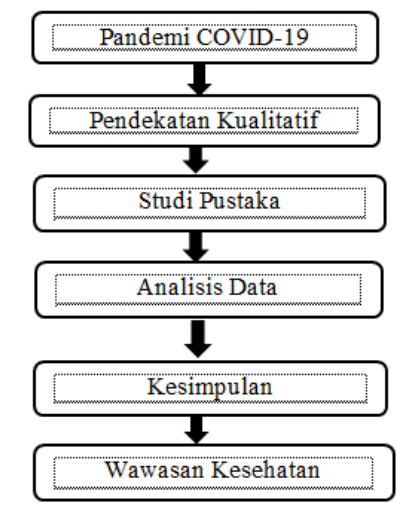

Gambar 1. Bagan Metodologi Penelitian 


\section{PRIMARY: JURNAL PENDIDIKAN GURU SEKOLAH DASAR \\ VOLUME 9 NOMOR 4 AGUSTUS 2020 \\ ISSN: 2303-1514 |E-ISSN: 2598-5949 \\ DOI : http://dx.doi.org/10.33578/jpfkip.v9i4.7954 \\ https://primary.ejournal.unri.ac.id/index.php/JPFKIP}

\section{HASIL DAN PEMBAHASAN}

Bahasa Indonesia merupakan salah satu mata pelajaran yang diajarkan di SD/MI. Di tengah pandemi COVID-19 ini mengembangkan materi ajar bahasa Indonesia dengan berwawasan kesehatan sangatlah penting, agar peserta didik dapat melindungi diri dari penularan virus tersebut. Disituasi seperti saat ini pembelajaran dilakukan secara daring, oleh karena itu kreativitas guru sangat diperlukan agar pesera didik tetap semangat belajar meskipun jarak jauh.

Kreativitas guru dalam menyajikan kegiatan pembelajaran di tengah pandemi COVID19 ini sangat diperlukan untuk mendukung perkembangan dan menstimulus kecerdasan peserta didik. Seperti memberi tugas sesuai dengan tema pembelajaran yang telah dirancang. Mengembangkan materi ajar dengan berwawaan kesehatan pada tema yang hendak diajarkan kepada peserta didik akan sangat bermanfaat untuk memberikan edukasi kepada peserta didik agar memahami tentang pentingnya menjaga kebersihan agar terhindar dari penularan virus corona. Pada tema 4 tentang Hidup Bersih dan Sehat yang diajarkan di kelas 2 SD/MI dalam materi bahasa Indonesia terdapat KD 3.4) Mengenal kosakata dan konsep tentang lingkungan sehat dan lingkungan tidak sehat dilingkungan sekitar serta cara menjaga kesehatan lingkungan dalam bahasa Indonesia atau bahasa daerah melalui teks tulis, lisan dan visual. KD 4.4) Menyajikan penggunaan kosakata bahasa Indonesia yang tepat atau bahasa daerah hasil pengamatan tentang lingkungan sehat dan lingkungan tidak sehat dilingkungan sekitar serta cara menjaga kesehatan lingkungan dalam bentuk teks, tulis, lisan, dan visual. Dalam hal ini guru dapat mengembangkan materi dengan memberikan wawasan tentang pola hidup bersih guna mencegah penularan virus corona.

Pada tema 4 tentang Hidup Bersih dan Sehat, disini guru mengembangkan materi Hidup Bersih dan Sehat dalam kehidupan sehari-hari dengan mengaitkan pentingnya menjaga kebersihan dan kesehatan di masa pandemi COVID-19 saat ini. Seperti pada materi berikut ini tentang Rumah yang Bersih Menyehatkan.

\section{Rumah yang Bersih Menyehatkan}

Rumah Dayu bersih. Rumah yang bersih banyak manfaatnya. Rumah Dayu terlihat rapi, indah, dan nyaman. Dayu dan keluarga juga terhindar dari penyakit. Itulah sebabnya Dayu membiasakan hidup bersih dan sehat di rumah. Rumah yang bersih menyehatkan.

Rumah yang bersih ada ciri-cirinya. Rumah Dayu tidak ada sampah berserakan. Debu-debu selalu dibersihkan. Peralatan rumah tangga juga tersusun rapi. Rumah Dayu juga dicat dengan warna yang menarik. Rumah Dayu terasa aman dan nyaman.

\section{Gambar 2. Materi Bahasa Indonesia}

Sumber: Buku Siswa SD/MI Kelas II TEMA 4 Hidup Bersih dan Sehat, 2017

Guru menjelaskan tentang Rumah yang Bersih Menyehatkan kepada peserta didik dan mengembangkannya dengan memberikan edukasi tentang tata cara menjaga kebersihan diri agar terhindar dari penularan virus corana. Saat ini pemerintah memberlakukan pembelajaran dengan sistem daring, meskipun melalui daring guru harus menanamkan kepada peserta didik tentang 


\section{PRIMARY: JURNAL PENDIDIKAN GURU SEKOLAH DASAR}

VOLUME 9 NOMOR 4 AGUSTUS 2020

ISSN: 2303-1514 |E-ISSN: 2598-5949

pentingnya menjaga kebersihan agar terhindar dari berbagai macam penyakit termasuk virus corona. Disini guru menjelaskan dan memberikan pengertian kepada peserta didik tentang bahayanya virus corona sehingga pembelajaran dilakukan secara daring.

Guru memberikan kesempatan kepada peserta didik untuk mengungkapkan dan mengomunikasikan perasaan mereka tentang wabah COVID-19. Mendiskusikan berbagai reaksi yang peserta didik ungkapkan dan menjelaskan bahwa semuanya itu normal dalam keadaan yang tidak biasa. Guru memberikan pengertian kepada peserta didik agar tidak terlalu panik dan takut, akan tetapi jangan meremehkan sehingga tidak memperhatikan kebersihan dan kesehatan, karena menjaga kebersihan dan Kesehatan sangatlah penting. Guru memperkenalkan konsep pembatasan sosial (menghindari keramaian, berdiri lebih jauh dari teman-teman, tidak bersentuhan, dan lain sebagainya), berfokus pada kebiasaan yang sehat seperti sering mencuci tangan, menutup batuk dan bersin, dan menggunakan masker (Lisa, 2020).

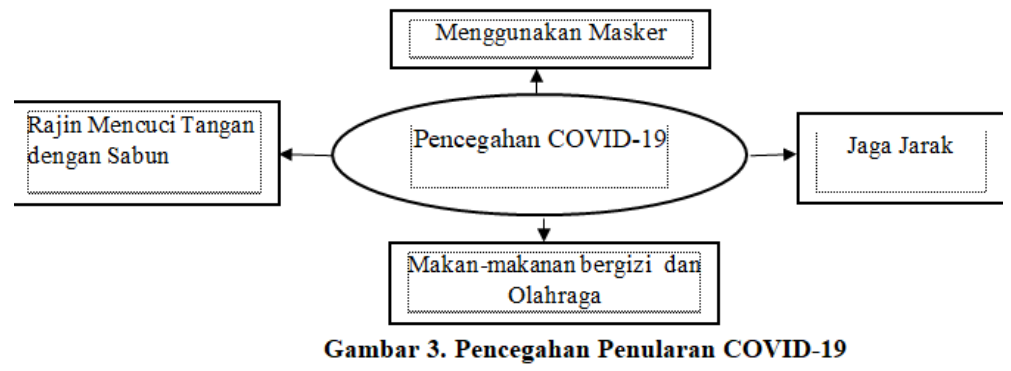

Melalui sistem daring guru dapat menyampaikan materi pembelajaran tersebut dengan video tutorial untuk memudahkan pemahaman peserta didik (Batubara dan Batubara, 2020). Setelah guru selesai menyampaikan materi guru dapat memberikan tugas kepada peserta didik untuk membuat teks tentang menjaga kesehatan agar terhindar dari penularan COVID-19 atau membuat gambar mengenai pencegahan penularan COVID-19. Mengembangkan materi ajar bahasa

\section{SIMPULAN DAN REKOMENDASI}

Hasil penelitian menunjukkan bahwa mengembangkan materi ajar bahasa Indonesia dengan berwawasan kesehatan sangat penting agar peserta didik dapat memahami pentingnya menjaga kebersihan dan kesehatan di tengah pandemi COVID-19. Dengan memberikan wawasan kesehatan, peserta didik mengetahui cara-cara untuk menjaga diri agar terhindar dari penularan COVID-19.
Indonesia dengan berwawasan kesehatan untuk mencegah penularan COVID-19 akan sangat bermanfaat bagi peserta didik, karena dengan dengan mengaitkan materi ajar dengan berwawasan kesehatan khususnya pada materi bahasa Indonesia akan memudahkan pemahaman peserta didik tentang pentingnya hidup sehat dan bersih agar terhindar dari berbagai macam penyakit termasuk virus corona yang sedang mewabah pada saat ini.

Penelitian ini merekomendasikan agar guru dapat mengembangkan materi ajar dengan berwawasan kesehatan khsusnya pada materi ajar bahasa Indonesia sebagai upaya guru untuk memberikan edukasi tentang cara-cara pencegahan penularan COVID-19 kepada peserta didik usia dasar. Sehingga peserta didik dapat menerapkan cara-cara tersebut untuk melindungi diri dari penularan COVID-19. 


\section{PRIMARY: JURNAL PENDIDIKAN GURU SEKOLAH DASAR \\ VOLUME 9 NOMOR 4 AGUSTUS 2020 \\ ISSN: 2303-1514 |E-ISSN: 2598-5949 \\ DOI : http://dx.doi.org/10.33578/jpfkip.v9i4.7954 \\ https://primary.ejournal.unri.ac.id/index.php/JPFKIP}

\section{DAFTAR PUSTAKA}

Andesta, D. (2018). Analisis Kebutuhan Anak Usia Dasar dan Implikasinya dalam Penyelenggaraan Pendidikan. JIP: Jurnal Ilmiah PGMI, 4(1), 82-97.

Batubara, H. H., \& Batubara, D.S. (2020). Penggunaan Video Tutorial Untuk Mendukung Pembelajaran Daring di Masa Pandemi Virus Corona. Muallimuna: Jurnal Madrasah Ibtidaiyah, 5(2), 21.

Bender, L. (2020). Pesan dan Kegiatan Utama Pencegahan dan Pengendalian Covid 19 di Sekolah. UNICEF New York.

Coronaviridae Study Group of the International Committee on Taxonomy of Viruses. (2020). The Species Severe Acute Respiratory Syndrome-Related Coronavirus: Classifying 2019-NCoV and Naming It SARS-CoV-2. Nature Microbiology, $5(4), 536-44$..

Depdiknas. (2008). Panduan Pengembangan Materi Pembelajaran.

Putra, N. (2012). Metode Penelitian Kualitatif Pendidikan. Jakarta: PT. Raja Grafindo Persada.

Shaharudin, M.R., Pani, J.J., Mansor, S.W., \& Elias, S.J. (2010). Factors Affecting Purchase Intention of Organic Food in Malaysia's Kedah State. Cross-Cultural Communication, 6(2), 105-116.

Sugiono. (2013). Metode Penelitian Pendidikan Pendekatan Kuantitatif, Kualitatif, dan $R \& D$. Bandung: Alfabeta.

Suharjana. (2012). Healthy Living Habits and Values Character Education. Jurnal Pendidikan Karakter, 2(2), 13.

Surat Edaran. (2020). Tentang Pencegahan Corona Virus Disease (COVID-19) Pada Satuan Pendidikan.

Susilo, A., Rumende, C.M., Pitoyo, C.W., Santoso, W. D., Yulianti, M., Herikurniawan, Sinto, R., et al. (2020). Coronavirus Disease 2019: Tinjauan Literatur Terkini. Jurnal Penyakit Dalam Indonesia, 7(1), 45.

Tematik Terpadu Kurikulum 2013. (2017). Tema 4 Hidup Bersih dan Sehat Buku Siswa SD/MI Kelas II. Edisi Revisi Jakarta: Kementian Pendidikan dan Kebudayaan.
Thaib, D., Wahyudin, D., Rahmawati, Y., \& Cepi Riyana. (2017). Studi Analisis Kebutuhan Terhadap Pengembangan Model Blended Learning Pada Sistem Pendidikan Jarak Jauh Untuk Meningkatkan Kompetensi Lulusan. EduHumaniora | Jurnal Pendidikan Dasar Kampus Cibiru, 8(2), 107.

Tomlinson, B. (1998). Materials Development in Language Teaching. Cambridge: Cambridge University Press.

UU. (2009). Undang-Undang Republik Indonesia Nomor 36 Tahun 2009 Tentang Kesehatan.

UU. (2018). Undang-Undang Republik Indonesia Nomor 6 Tahun 2018 Tentang Kekarantinaan Kesehatan.

Wahyanti, C. M., \& Sutopo, J. (2013). Pengembangan Materi Ajar Berbasis Pendidikan Karakter Bagi Guru Bahasa Inggris SD Kecamatan Tembalang. Jurnal Penerapan Teknologi dan Pembelajaran, 11(2), 6.

Yunus, N., \& Rezki, A. (2020). Kebijakan Pemberlakuan Lockdown Sebagai Antisipasi Penyebaran Corona Virus Covid-19. SALAM, 7(3), 227-38.

Zed, M. (2008). Metode Penelitian Kepustakaan. Jakarta: Yayasan Obor Indonesia. 